\title{
Plasma Biomarkers in Pediatric Patients Undergoing Cardiopulmonary Bypass
}

\author{
MELINDA E. LULL, NURGUL CARKACI-SALLI, WILLARD M. FREEMAN, JOHN L. MYERS, FRANK M. MIDGLEY, \\ NEAL J. THOMAS, STEPHEN J. KIMATIAN, KENT E. VRANA, AND AKIF ÜNDAR
}

Department of Pharmacology [M.E.L., N.C.-S., W.M.F., K.E.V.], Department of Surgery [J.L.M., F.M.M., S.J.K., A.U.], Department of Pediatrics [J.L.M., F.M.M., NJT., S.J.K., A.U.], Department Bioengineering [A.U.], Pennsylvania State University College of Medicine, Hershey, Pennsylvania 17033

\begin{abstract}
It is critical to identify at-risk patients and minimize the deleterious effects of cardiopulmonary bypass (CPB) procedures in pediatric populations. The present study screened the plasma proteome of pediatric patients undergoing CPB procedures to identify potential clinical biomarkers related to tissue damage, inflammation, or other pathologies. Blood samples were collected at five different time points from 10 children undergoing a CPB procedure. Plasma was isolated and analyzed using two-dimensional differential in-gel electrophoresis and matrix-assisted laser desorption ionization time of flight mass spectrometry. Levels of differentially regulated proteins identified by two-dimensional differential in-gel electrophoresis, and related proteins were then measured in all time points and patients. As well, associated small molecules and ions were measured. The present study identified 13 proteins and protein isoforms altered in expression, including hemopexin, ceruloplasmin, inter-alpha inhibitor $\mathrm{H} 4$, and alpha-2-macroglobulin. Immunoblot analysis revealed significant decreases in each of these proteins during the CPB procedure. Significant changes in the levels of copper, iron, $\mathrm{Hb}$, epinephrine, norepinephrine, and serotonin were observed. The potential markers of pathology (inflammation, oxidative stress) identified during this preliminary study may illuminate opportunities for preventative measures and/or treatments during and following CPB procedures in pediatric patients. (Pediatr Res 63: 638-644, 2008)
\end{abstract}

$\mathrm{A}$ lthough cardiopulmonary bypass (CPB) methods are well optimized and mortality rates from pediatric CPB continue to decrease $(1,2)$, surgery-related pathologies are still a major concern. In fact, changes have been observed in levels of cytokines (3), and CD antigens (4) in the blood following $\mathrm{CPB}$ procedures. Changes in such molecules may reflect tissue damage, inflammation, and other pathologies that could affect both the long- and short-term patient outcome. These markers of pathology are risk factors for in-hospital or post-discharge morbidity and mortality in pediatric CPB patients $(5,6)$. A more complete catalog of the circulating changes accompanying pediatric CPB surgeries may enable better prevention and treatment of complications.

Received October 16, 2007; accepted January 18, 2008

Correspondence: Kent E. Vrana, Ph.D., Department of Pharmacology, Penn State College of Medicine, 500 University Drive, P.O. Box 850, Hershey, PA 17033; e-mail: kvrana@psu.edu

Supported by GM38931 (K.E.V.) and "The Department of Pediatrics Seed Funds" by 217-51HY (A.U.).

M.E.L. and N.C.S. contributed equally to this work. The senior authors, K.E.V. and A.U., contributed equally to this work.
Although survival with good acute outcomes after surgery is increasingly likely with pediatric CPB procedures, neurodevelopmental complications such as lower intelligence, motor deficits, and impaired language skills remain a concern (7). In addition, a higher incidence of behavioral and attention problems have been reported in these patients $(8,9)$. Although the cause of such deficits has not been shown to result from the CPB procedure itself, it is important to identify the potential long-term effects of pediatric cardiac surgery on development.

Previous studies by our laboratory have used proteomic techniques-specifically two-dimensional differential in-gel electrophoresis (2-DIGE) - to examine the proteomic profile of various tissues and body fluids (10-12). We have previously applied these techniques to illuminate the proteomic profile of pediatric cardiac patients, revealing a number of changes in protein expression that occur during CPB procedures (11). Although other proteomic techniques were considered for this analysis, the statistical power and reproducibility of 2-DIGE analysis outweighed the potential for the visualization of a greater number of proteins. Plasma is the ideal source for such analysis as it is easily sampled from patients and reflects processes in all anatomical compartments. From these analyses, it is possible to derive surrogate biomarkers of disease processes that may ultimately affect patient outcomes.

There are, however, challenges to the examination of proteins present in whole plasma. Plasma protein concentrations encompass twelve orders of magnitude (13). As the top six most abundant plasma proteins account for over $85 \%$ of the total plasma protein mass, analysis of whole plasma masks the least abundant proteins (i.e., tissue leakage factors, cytokines, and growth factors) and possibly the most predictive biomarkers of CPB-related tissue damage and inflammation. The removal of these high abundance proteins therefore allows for the screening of over 1000 proteins present in human plasma $(11,13)$.

The current study used discovery proteomics to identify protein expression changes occurring during $\mathrm{CPB}$ procedures and confirmed these changes across time points before, during, and after surgery, as well as in a number of different

\footnotetext{
Abbreviations: CPB, cardiopulmonary bypass; 2-DIGE, 2-dimensional differential in-gel electrophoresis; ITI-H4, inter-alpha inhibitor H4; MALDI, matrix-assisted laser desorption ionization; ToF, time of flight
} 
patients. The central hypothesis is that CPB produces alterations in circulating molecules that may act as biomarkers of pathophysiology and organ dysfunction after $\mathrm{CPB}$ procedures.

\section{METHODS}

Patient characteristics and $\boldsymbol{C P B}$. Samples were collected from 10 pediatric patients after approval from the Penn State College of Medicine Institutional Review Board and consent forms were signed. Patient profiles are outlined in Table 1. CPB was performed using either the Capiox Baby Rx (Terumo Corporation) or the Lilliput (Dideco, SpA) as described previously in detail (11). Table 2 outlines the CPB parameters for each of the 10 patients. No dopamine, epinephrine or norepinephrine was administered to patients during or following CPB. For each patient, baseline samples were taken approximately $30 \mathrm{~min}$ before surgery (time point 1 ). Additional samples were taken 5 min after initiation of $\mathrm{CPB}$ (time point 2), at the end of $\mathrm{CPB}$ (immediately before weaning) (time point 3 ), $1 \mathrm{~h}$ postweaning from CPB (time point 4), and $24 \mathrm{~h}$ postweaning from CPB (time point 5).

Plasma processing and depletion. Blood was centrifuged and the plasma layer was removed and stored at $-80^{\circ} \mathrm{C}$ until analyzed. Removal of six high abundance proteins (albumin, transferrin, $\operatorname{IgG}, \operatorname{IgA}, \alpha 1$-antitrypsin, and haptoglobin) was carried out using the antibody-based human multiple affinity column (MARS column, Agilent Technologies) as previously described for serum depletion $(11,13)$. Plasma samples from a single patient (patient 3 ) at time points 2 and 4 were chosen for depletion and 2-DIGE analysis. Depleted plasma was stored at $-20^{\circ} \mathrm{C}$ until use.

2-DIGE. 2-DIGE and gel analysis was performed as previously detailed using samples $(10,11)$. Depleted plasma was purified from lipids and nucleic acids by precipitation (2D-Cleanup, GE Healthcare) and quantified using the 2D-Quant protein assay (GE Healthcare). Samples were brought to a $\mathrm{pH}$ between 8.0 and 9.0 and $50 \mu \mathrm{g}$ of each sample were labeled using $\mathrm{Cy} 3$ or $\mathrm{Cy} 5$

Table 1. Patient characteristics

\begin{tabular}{|c|c|c|c|c|}
\hline Patient & Sex & $\begin{array}{l}\text { Age } \\
\text { (mo) }\end{array}$ & $\begin{array}{l}\text { Weight } \\
(\mathrm{kg})\end{array}$ & Brief description of defect/repair \\
\hline 1 & Male & 3 & 5.4 & Tetralogy of Fallot \\
\hline 2 & Female & 5 & 6 & Atrial and ventricular septal defect \\
\hline 3 & Male & 8 & 9.4 & $\begin{array}{l}\text { Glenn shunt and takedown of } \\
\text { Blalock-Taussig shunt }\end{array}$ \\
\hline 4 & Male & 12 & 6.3 & Tetralogy of Fallot \\
\hline 5 & Female & 1 & 5.2 & Tetralogy of Fallot \\
\hline 6 & Female & 9 & 6 & $\begin{array}{l}\text { Mitral valve repair and ventricular } \\
\text { septal defect }\end{array}$ \\
\hline 7 & Female & 48 & 15 & Atrial septal defect \\
\hline 8 & Male & 24 & 11.6 & Completion of Fontan \\
\hline 9 & Male & 3 & 5 & Atrial and ventricular septal defect \\
\hline 10 & Male & 36 & 16.1 & Aortic valvuloplasty \\
\hline
\end{tabular}

dye (GE Healthcare). Two hundred micrograms of unlabeled protein were used for a picking gel for mass spectrometry identification of protein species. Samples were focused on $24 \mathrm{~cm} \mathrm{pH} \mathrm{4-7} \mathrm{isoelectric} \mathrm{focusing} \mathrm{gels} \mathrm{(GE}$ Healthcare) and separated by molecular weight on $10 \%$ polyacrylamide gels. On completion of electrophoresis, the picking gel was stained with SyproRuby (Bio-Rad) and all gels were imaged on a Typhoon 9410 scanner (GE Healthcare). Analysis of gel images was performed using DeCyder 6.5 software (GE Healthcare) to detect spots and calculate relative expression value.

Matrix-assisted laser desorption ionization time of flight (MALDI-ToF) mass spectrometry. Tandem MALDI-ToF (MALDI-ToF/ToF) mass spectrometry was performed as described previously (10). Tandem mass spectrometry was performed on the 4800 Proteomics Analyzer (Applied Biosystems) and data were submitted to a MASCOT search engine for protein identification using GPS Explorer 3.6 software (Applied Biosystems). Proteins were considered identified if the combined protein score confidence interval from tandem mass spectrometry was greater than $97 \%$.

Western blot analysis. Whole plasma from each time point and patient was diluted 10-fold with PBS. The resulting diluted plasma was assayed for protein concentration using the BCA Protein Assay Kit (Pierce Endogen). Fifteen micrograms of each sample was resolved by denaturing SDS-PAGE gel on $4-12 \%$ Criterion precast gels (Bio-Rad). Protein was then transferred onto Immobilin-P transfer membranes (Millipore Corporation) and blocked in $5 \%$ milk, PBS $+0.1 \%$ Tween 20 . Blots were then probed with antibodies for inter-alpha inhibitor H4 (ITI-H4; Santa Cruz Biotechnology, Inc.), ceruloplasmin (Novus Biologicals), hemopexin (Novus Biologicals), transferrin (Novus Biologicals) and alpha-2-macroglobulin (Sigma Chemical Co.Aldrich). Membrane bound antibodies were detected with horseradish peroxidase conjugated secondary antibodies and visualized using enhanced chemiluminescence (Perkin-Elmer). Bands were quantified using Image Quant TL (GE Healthcare) and values were normalized to the volume of plasma loaded.

$\mathrm{Hb}$, iron, and copper determination. Iron, copper, and plasma $\mathrm{Hb}$ levels were measured from plasma using specific assay procedures (QuantiChrom Iron Assay Kit, QuantiChrom Copper Assay Kit; QuantiChrom Hb Assay Kit; BioAssay Systems Hayward, CA). Concentrations were calculated using linear regression of standard curve dilutions.

ELISA assays. Assays for serotonin (5-HT), dopamine, epinephrine, and norepinephrine content were performed using ELISA kits (and standard dilution curves) designed for small volumes (IBL, Minneapolis, MN). Ascorbic acid $\left(10^{-4} \mathrm{M}\right)$ was added to the plasma to protect the samples from oxidation.

Statistical analysis. All data are presented as mean \pm SEM. Statistical analysis was performed with repeated measures ANOVA followed by a post hoc paired $t$ test. A $p$ value $<0.05$ was considered significant.

\section{RESULTS}

2-DIGE analysis. There were 1379 spots visualized following 2-DIGE analysis, of which $79(5.7 \%)$ were altered by $50 \%$ or more (11). Figure $1 A$ shows an image of the 2-DIGE gel with protein species from time point 2 in green, and time point

Table 2. $C P B$ parameters

\begin{tabular}{|c|c|c|c|c|c|c|c|c|c|c|c|c|c|c|c|}
\hline \multirow[b]{2}{*}{ Patient } & \multirow[b]{2}{*}{$\begin{array}{l}\text { BSA } \\
\text { (m2) }\end{array}$} & \multirow[b]{2}{*}{$\begin{array}{l}\text { CPB } \\
\text { time } \\
(\min )\end{array}$} & \multirow{2}{*}{$\begin{array}{c}\text { Aortic } \\
\text { clamp } \\
\text { time } \\
\text { (min) }\end{array}$} & \multirow[b]{2}{*}{ Oxygenator } & \multirow{2}{*}{$\begin{array}{c}\text { Lowest } \\
\text { nasal } \\
\text { temp. } \\
\left({ }^{\circ} \mathrm{C}\right)\end{array}$} & \multirow{2}{*}{$\begin{array}{c}\text { Urine } \\
\text { output } \\
\text { during } \\
\text { CPB } \\
(\mathrm{mL})\end{array}$} & \multirow[b]{2}{*}{$\begin{array}{c}\text { Ultra- } \\
\text { filtrate } \\
(\mathrm{mL})\end{array}$} & \multirow[b]{2}{*}{$\begin{array}{l}\text { MUF } \\
(\mathrm{mL})\end{array}$} & \multicolumn{2}{|c|}{ Cardioplegia } & \multicolumn{3}{|c|}{ Priming solution } & \multirow[b]{2}{*}{$\begin{array}{c}\text { On-bypass } \\
\text { Blood } \\
(\mathrm{mL})\end{array}$} & \multirow[b]{2}{*}{$\begin{array}{c}\text { Post-bypass } \\
\text { FFP (mL) }\end{array}$} \\
\hline & & & & & & & & & $\begin{array}{c}\text { Temp. } \\
\left({ }^{\circ} \mathrm{C}\right)\end{array}$ & $\begin{array}{c}\text { Total } \\
\text { amount } \\
\text { (times) }\end{array}$ & $\begin{array}{l}\text { Plasmalyte } \\
\quad(\mathrm{mL})\end{array}$ & $\begin{array}{c}\text { PRBC } \\
(\mathrm{mL})\end{array}$ & $\begin{array}{c}25 \% \\
\text { Mannitol } \\
(\mathrm{g})\end{array}$ & & \\
\hline 1 & 0.28 & 85 & 71 & A & 27.2 & 100 & 0 & 550 & 4.6 & $50(2)$ & 450 & 250 & 0 & 250 & 185 \\
\hline 2 & 0.32 & 44 & 29 & $\mathrm{~A}$ & 31.5 & 55 & 0 & 500 & 4.2 & $48(1)$ & 400 & 250 & 0 & 0 & 150 \\
\hline 3 & 0.42 & 53 & - & A & 35.2 & 9 & 0 & 350 & - & - & 275 & 250 & 5 & 0 & 240 \\
\hline 4 & 0.34 & 153 & 55 & A & 27.3 & 15 & 0 & 300 & 5.6 & $42(2)$ & 275 & 250 & 3.25 & 0 & 160 \\
\hline 5 & 0.27 & 109 & 61 & B & 26.7 & 25 & 0 & 500 & 3.8 & $76(2)$ & 350 & 200 & 2.5 & 0 & 210 \\
\hline 6 & 0.34 & 85 & 47 & A & 33.6 & 40 & 100 & 650 & 5.5 & $130(2)$ & 250 & 200 & 2.5 & 0 & 190 \\
\hline 7 & 0.66 & 39 & 26 & $\mathrm{C}$ & 34.7 & 15 & 0 & 900 & 3.7 & $60(1)$ & 600 & 0 & 0 & 0 & 0 \\
\hline 8 & 0.51 & 161 & 118 & $\mathrm{C}$ & 30.6 & 40 & 100 & 600 & 4.5 & $128(4)$ & 600 & 250 & 0 & 0 & 200 \\
\hline 9 & 0.28 & 70 & 56 & B & 29.6 & 10 & 150 & 500 & 4.6 & $48(2)$ & 280 & 250 & 0 & 150 & 190 \\
\hline 10 & 0.67 & 73 & 38 & $\mathrm{C}$ & 30 & 70 & 0 & 850 & 4.1 & 90 (1) & 300 & 200 & 7.5 & 50 & 160 \\
\hline
\end{tabular}

As part of the priming solution, all patients were given $50 \mathrm{~mL}$ of $25 \%$ albumin, 1000 units of heparin and $15 \mathrm{mEq}$ of $\mathrm{NaHCO}_{3}$, with the exception of patient 9 who was given $25 \mathrm{mEq}$ of $\mathrm{NaHCO}_{3}$. Additionally, no platelets were given post-bypass, and only patient 8 was given blood post-bypass (250 mL). Type of oxygenator: A, capiox baby RX; B, lilliput I; C, lilliput II.

BSA, body surface area; FFP, fresh frozen plasma; mEq, milli-equivalents; MUF, modified ultrafiltration; PRBC, packed red blood cells. 
A)

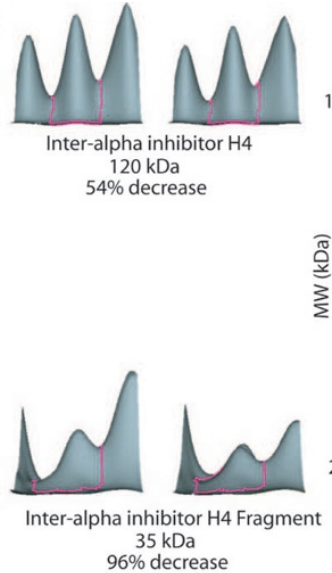

B)

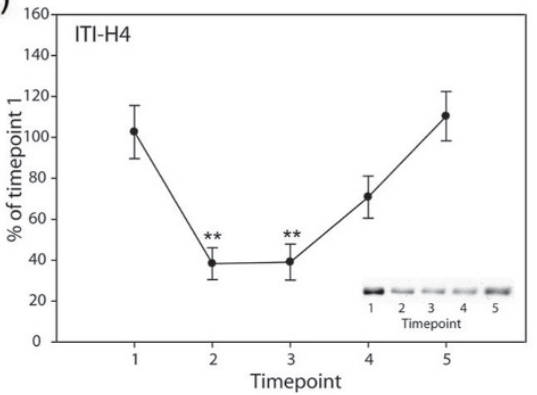

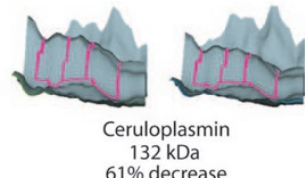
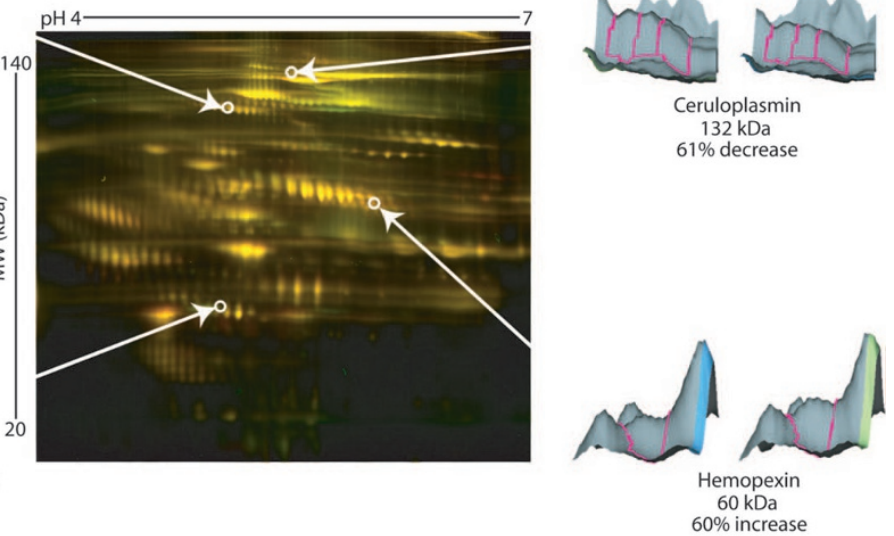

61\% decrease

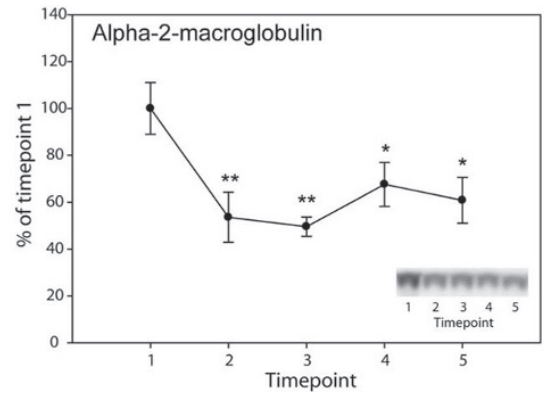

Figure 1. 2-DIGE identification of targets. (A) Sample from time points 2 and 4 were analyzed using 2-DIGE. The image shown is the resulting gel, where separated proteins range in $\mathrm{pI}$ from $\mathrm{pH} 4-7$ (left to right) and in molecular weight from 140 to $20 \mathrm{kD}$ (top to bottom). Areas in yellow represent proteins that were unchanged between time points, where those that are red or green represent increases and decreases between time points 2 and 4, respectively. Three-dimensional images of each spot are created using DeCyder 6.5 software based on signal intensity and spot volume. (B) Protein was measured from 10 patients at all five time points during surgery using western blot analysis. Levels of ITI-H4 and alpha-2-macroglobulin were significantly reduced during the surgery whereas levels of alpha-2-macroglobulin remained low $24 \mathrm{~h}$ after surgery. $* p<0.05 ; * * p<$ 0.01

Table 3. Changed proteins

\begin{tabular}{llll}
\hline \multicolumn{1}{c}{ Protein } & \% change & Accession number & \multicolumn{1}{c}{ General function } \\
\hline $\begin{array}{l}\text { Increases } \\
\text { Hemopexin } \dagger\end{array}$ & 60 & trm Q9BS19 & Heme scavenging \\
Alpha-1-antichymotrypsin precursor & 53 & gb AAA51560.1 & Plasma protease inhibitor \\
Decreases & & spt P01023 & Precursor, major plasma proteinase inhibitor \\
Alpha-2-macroglobulin precursor* & 81 & prf 1009194A & Major plasma proteinase inhibitor \\
Alpha-2-macroglobulin* & 62 & rf NP_002209.2 & Serine protease \\
Inter-alpha inhibitor H4* & 54 & spt P01024 & Precursor, acute phase response \\
Complement C3 precursor* & 85 & gb AAA51748.1 & Precursor, lipid transport and metabolism \\
Apolipoprotein A-IV precursor & 52 & trm Q13784 & Lipid transport and metabolism \\
Apolipoprotein A-IV (fragment) & 85 & rf NP_002209.2 & Serine protease \\
Inter-alpha inhibitor H4 (fragment) & 96 & spt P02649 & Precursor, lipid transport and metabolism \\
Apolipoprotein E precursor & 52 & gb AAA51747.1 & Precursor, lipid transport and metabolism \\
Proapolipoprotein A-I* & 60 & trm Q9BS19 & Heme scavenging \\
Hemopexin $\dagger$ & 54 & dbj BAA08084.1 & Copper containing/iron metabolism \\
Ceruloplasmin* & 58 & &
\end{tabular}

* Proteins denoted by an asterisk were independently identified in multiple isoforms (members of a charge train within a single molecular weight). Such multiple identifications ranged from 2 to 10 independent species. The reported percent change reflects the average change for all species.

$\dagger$ Hemopexin is shown to both increase and decrease. These identifications were made from opposite ends of a charge train and may reflect posttranslational modifications of the same protein.

4 in red. Spots represented as yellow are unchanged between samples, whereas those in shades of green or red indicate decreases and increases from time point 2 to 4 , respectively. Of the changes, 14 spots were up-regulated and 65 were down-regulated. MALDI-ToF/ToF analysis of robotically excised gel plugs has lead to the identification of 13 unique protein changes (Table 3), and a number of proteins that remain unchanged (Table 4).

For both changed and unchanged species, many are members of charge trains; that is, a series of protein spots at the same molecular weight, but different $\mathrm{pI}$ values across the gel. This generally indicates different isoforms or posttranslational modifications of a single protein. Such instances, where mul- tiple identifications of a single protein were obtained, are marked with asterisks in Tables 3 and 4. In the case of changed protein species, percent change has been averaged for all the identified spots of a single protein.

Immunoblot analysis of proteins of interest. To identify proteins of interest, literature searches were made of differentially expressed proteins using protein accession numbers. From this literature search, four protein changes were selected for further analysis (based on biologic functions related to inflammation and oxidative stress). ITI-H4, both full length $(120 \mathrm{kD})$ and fragment forms $(35 \mathrm{kD})$, was identified to be decreased by $54 \%$ (two spots identified, each decreased by $54 \%$ ) and $96 \%$, respectively (Fig. 1A, left). Ceruloplasmin, a 
Table 4. Unchanged proteins

\begin{tabular}{|c|c|c|}
\hline Protein & Accession number & General function \\
\hline $\begin{array}{l}\text { Complement } \mathrm{C} 1 \mathrm{~s} \\
\text { component precursor }\end{array}$ & spt Q9UCV4 & Precursor, serine protease \\
\hline Afamin precursor & spt P43652 & $\begin{array}{l}\text { Precursor, albumin family, } \\
\text { vitamin E binding } \\
\text { protein }\end{array}$ \\
\hline Gelsolin precursor* & spt P06396 & $\begin{array}{l}\text { Precursor, plasma actin } \\
\text { clearance }\end{array}$ \\
\hline Serotransferrin precursor & spt P02787 & Precursor, iron metabolism \\
\hline Complement 9 & emb CAA69849.1 & $\begin{array}{l}\text { Component, membrane } \\
\text { attack complex }\end{array}$ \\
\hline Antithrombin III & pbd aATH_A & Coagulation inactivator \\
\hline Alpha-macroglobulin* & gb AAA51552.1 & $\begin{array}{l}\text { Major plasma proteinase } \\
\text { inhibiter }\end{array}$ \\
\hline Fibrinogen gamma* & prf 0602239A & $\begin{array}{l}\text { Precursor glycoprotein, } \\
\text { clotting factor }\end{array}$ \\
\hline Serum paraoxonase & gb AAA60143.1 & Plasma arylesterase \\
\hline $\begin{array}{l}\text { Apolipoprotein A-IV } \\
\text { precursor }\end{array}$ & gb AAA51748.1 & $\begin{array}{l}\text { Precursor, lipid transport } \\
\text { and metabolism }\end{array}$ \\
\hline SP40,40 & gb AAA60567.1 & Unknown \\
\hline Transthyretin & gb AAA61181.1 & $\begin{array}{l}\text { Prealbumin, transport } \\
\text { protein for retinol and } \\
\text { thyroxine }\end{array}$ \\
\hline Proapolipoprotein A-I* & gb AAA51747.1 & $\begin{array}{l}\text { Precursor, lipid transport } \\
\text { and metabolism }\end{array}$ \\
\hline $\begin{array}{l}\text { Serum amyloid } \mathrm{P} \\
\text { component }\end{array}$ & pdb 1SAC_A & Fibrous protein aggregate \\
\hline $\begin{array}{l}\text { Amyloidogenic } \\
\text { transthyretin variants }\end{array}$ & pdb 1TSH_A & $\begin{array}{l}\text { Prealbumin, transport } \\
\text { protein for retinol and } \\
\text { thyroxine }\end{array}$ \\
\hline Fibrin beta & prf 0401173A & Clotting factor \\
\hline $\begin{array}{c}\text { Human vitamin } \mathrm{D} \\
\text { binding protein }\end{array}$ & pdb 1J78_A & $\begin{array}{l}\text { Albumin family, vitamin D } \\
\text { binding }\end{array}$ \\
\hline Kininogen* & rf NP_000884.1 & $\begin{array}{l}\text { Cofactor of coagulation } \\
\text { and inflammation }\end{array}$ \\
\hline Thrombin & trm Q7Z7P3 & Blood coagulation \\
\hline Alpha-1-B-glycoprotein & pir OMHU1B & Platelet membrane receptor \\
\hline Hemopexin & trm Q9BS19 & Heme scavenging \\
\hline $\begin{array}{l}\text { Complement factor B } \\
\text { precursor* }\end{array}$ & spt P00751 & $\begin{array}{l}\text { Zymogen, complement } \\
\text { activation }\end{array}$ \\
\hline Hemopexin precursor & spt P02790 & Heme scavenging \\
\hline
\end{tabular}

* Proteins denoted by an asterisk were independently identified in multiple isoforms (members of a change train within a single molecular weight). Such multiple identifications ranged from 2 to 3 independent species.

$132 \mathrm{kD}$ protein, was decreased by an average of $58 \%$ (average of three spots, 61\%, 61\%, and 52\%) (Fig. 1A, top right). Hemopexin, a $60 \mathrm{kD}$ protein, was both increased by $60 \%$ at a higher $\mathrm{pH}$ form, and decreased by $54 \%$ at a lower $\mathrm{pH}$ form (Fig. 1A, bottom right, Table 3). Finally, a large number of alpha-2-macroglobulin spots were altered by an average of $62 \%$ (data not shown).

Using immunoblot analysis, ITI-H4, ceruloplasmin, hemopexin, and alpha-2-macroglobulin levels were analyzed in 10 patients. All five time points were included in this analysis to determine the pattern of protein levels during and after the CPB procedure (Figs. $1 B$ and 2). A significant reduction of approximately $60 \%$ in levels of ITI-H4 was observed between time point 1 and time points 2 and 3 ( $p<0.001$ for both comparisons) (Fig. 1B, left panel). A 30\% reduction from time point 1 to time point 4 was also observed $(p<0.01)$. A significant reduction was also seen between time point 5 and time points 2,3 , and 4 ( $p<0.001, p<0.001$, and $p<0.05$, respectively). During the surgical repair itself, time points 2 and 3 were significantly reduced from time point 4 , immediately after surgery ( $p<0.05$ for both comparisons). Levels of alpha-2-macroglobulin were observed to be decreased by $40-50 \%$ at time points 2 ( $p<0.001), 3$ ( $p<0.001), 4(p<$ $0.01)$, and $5(p<0.05)$ compared with time point 1 (Fig. $1 B$, right panel).

Modest reductions in ceruloplasmin levels at time points 2 and 3 were observed compared with time point $1(p<0.01$ and $p<0.05$, respectively) (Fig. 2A). The initial 2-DIGE analysis showed that levels of hemopexin were increased between time points 2 and 4 (Fig. $1 B$, right panel), a change that was confirmed in the 10 patient analysis $(p<0.01)$ (Fig. $2 C$ ). Additionally, hemopexin is significantly reduced from time point 1 by $60 \%$ at time point $2,50 \%$ at time point 3 , and $30 \%$ at time point $4(p<0.001, p<0.001$, and $p<0.05$, respectively) (Fig. 2C). Levels of transferrin were also measured because of its involvement in iron metabolism, but no significant changes were observed (Fig. 2B).

Determination of copper and iron levels in plasma. Levels of copper were increased compared with baseline during and immediately following CPB (time point $3 ; p<0.01$ and time point 4; $p<0.001$ ) (Fig. 2A). In contrast to changes observed for copper, the levels of total iron in the plasma were significantly lower at time point $2(p<0.01)$
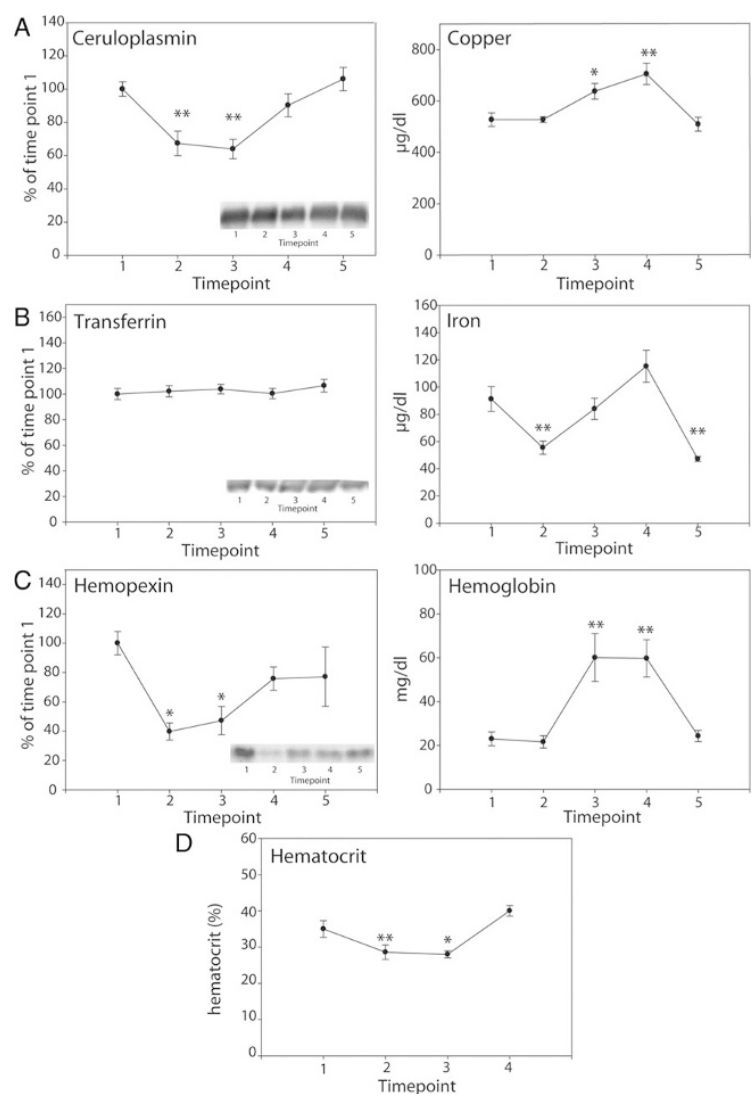

Figure 2. Effect of pediatric CPB procedures on plasma iron, copper, and related proteins. Measurements were made from samples taken at five time points before, during, and after surgery in related metals and proteins: $(A)$ ceruloplasmin and copper, $(B)$ transferrin and iron, $(C)$ hemopexin and $\mathrm{Hb}$, and $(D)$ hematocrit. The insets show representative western blot signals for ceruloplasmin, transferrin, and hemopexin. ${ }^{*} p<0.05$; ${ }^{* *} p<0.01$. 

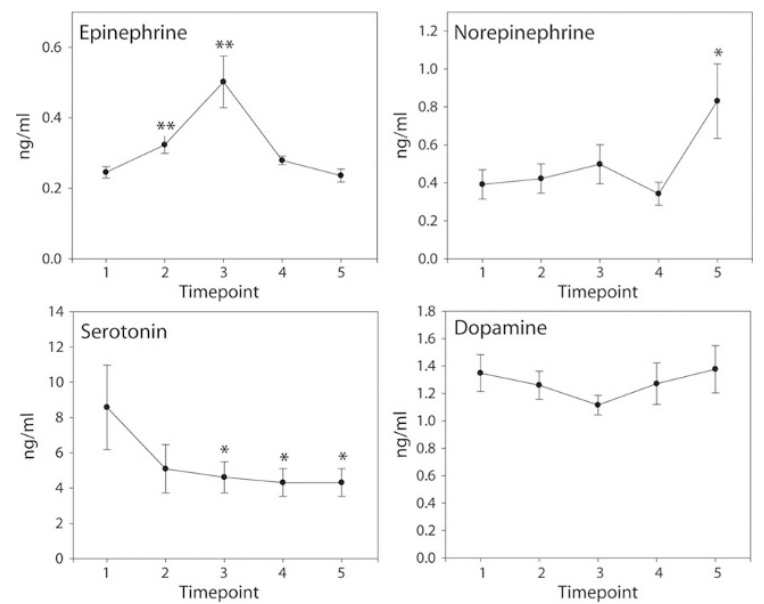

Figure 3. Effect of pediatric $\mathrm{CPB}$ procedures on levels of catecholamines and serotonin. Circulating serotonin and catecholamines were measured before surgery (baseline time point 1), at initiation of CPB (time point 2), on CPB but after surgery (time point 3), $1 \mathrm{~h}$ after CPB (time point 4), and $24 \mathrm{~h}$ after CPB (time point 5). * $p<0.05 ; * * p<0.01$.

and time point $5(p<0.01)$, as compared with baseline levels at time point 1 (Fig. $2 B$ ).

Analysis of hematocrit and Hb levels. Given that total iron will also include metal bound to $\mathrm{Hb}$ released during hemolysis, cell-free $\mathrm{Hb}$ was measured at each of the five time points in the 10 patients (Fig. $2 C$ ). In this case, $\mathrm{Hb}$ levels were elevated at time point $3(p<0.01)$ and time point $4(p<$ 0.001). Hb levels had normalized $24 \mathrm{~h}$ after surgery compared with baseline. Hematocrit levels were determined from blood samples taken during and immediately following CPB (time points 1-4). Significant decreases in hematocrit were observed at time points 2 and $3(p<0.01 ; p<0.05$, respectively) (Fig. 2D).

Biogenic amine levels. ELISA assays were used to assess the levels of bioactive biogenic amines-the catecholamines (dopamine, epinephrine, and norepinephrine) and serotonin (Fig. 3). Epinephrine levels rise during the course of the surgery compared with baseline (time points 2 and $3 ; p<0.01$ and $p<0.01$, respectively), but returned to normal $24 \mathrm{~h}$ after surgery (time point 5) (Fig. 3). Levels of norepinephrine were unchanged during the course of surgery, but were elevated at time point $5(p<0.05)$ (Fig. 3$)$. In contrast to the norepinephrine profile, serotonin produced an opposite pattern. Serotonin levels were significantly decreased at time points 3,4 and 5, compared with time point $1(p<0.05, p<0.05$, and $p<$ 0.05 , respectively) (Fig. 3). As a control, levels of dopamine were unchanged throughout the surgical intervention.

\section{DISCUSSION}

Using proteomic techniques to examine levels of plasma proteins has proven to be a useful tool to look for potential biomarkers in a number of pathologic conditions including Alzheimer's disease, heart disease, and others $(14,15)$. Additionally, plasma proteomic techniques have been used to profile disease states, risk profiles, and identify therapeutic options after cardiovascular surgery (16). The use of such techniques with pediatric cardiovascular surgery, specifically with $\mathrm{CPB}$, however, is limited $(11,17)$. In a previous report, we examined proteomic changes occurring during CPB procedures (11). Following this analysis, it was observed that $5.7 \%$ of the protein species observed were changed by $50 \%$ or more during $\mathrm{CPB}$ (changes ranged from a 50\% change to a more than $300 \%$ change). Although preliminary identification of these species by MALDI-ToF/ToF mass spectrometry only revealed ceruloplasmin to be changed, additional identification has revealed another 12 proteins as potential markers of CPB-related pathologies (Table 3).

Of specific interest is the apparent dysregulation of proteins containing or relating to the metabolism of metal ions (ceruloplasmin and hemopexin). Observed changes in these two metal-binding proteins has led us to test the hypothesis that levels of plasma metals, metal-binding and processing proteins, and circulating neurohormones dependent on metal homeostasis significantly change during pediatric CPB. Alterations in levels of these molecules could play a role in the development of complications that arise during and following CPB procedures.

The role of ceruloplasmin has been discussed previously with the finding of decreased levels after CPB (11). Ceruloplasmin regulates plasma copper binding and thereby controls peroxidation of iron allowing its association with transferrin. During CPB, we have documented a $40 \%$ decrease in ceruloplasmin levels. Although levels of ceruloplasmin have not been extensively studied in cardiac surgery, decreased serum levels have been associated with hepatic iron overload (18). Additionally, ceruloplasmin has been shown to be essential for iron homeostasis and neuronal survival (19). Decreased plasma levels of ceruloplasmin could therefore be predictive of pathologies resulting from dysregulated iron metabolism.

Changes in the levels of ceruloplasmin prompted an examination of copper and iron levels-metals directly related to the function of the protein. An increase in levels of copper during and immediately following CPB procedures is counterintuitive to what is expected with decreased ceruloplasmin levels. However, this increase could indicate the role of other copper-carrying proteins, or increases in free copper in the plasma. The role of decreased levels of ceruloplasmin in the observed iron deficiency could be related to a decrease in oxidation of iron, thereby preventing its ability to bind to transferrin and be transported into cells. Indeed, levels of transferrin, the major iron-carrying plasma protein, are unchanged, suggesting such an alternative source of deficiencies in iron.

The risk of postoperative iron deficiency could also be exacerbated by the increased clearance of $\mathrm{Hb}$. Normal iron levels for infants range from 100 to $250 \mu \mathrm{g} / \mathrm{dL}$, whereas adult levels range from 65 to $175 \mu \mathrm{g} / \mathrm{dL}$. Almost all pediatric patients undergoing CPB receive adult donor blood (to provide a priming volume for the pump system). The iron levels observed in these patients were normal before surgery, but were decreased following hemodilution with donor blood and, most importantly, remained decreased by $51 \%$ even $24 \mathrm{~h}$ after surgery. This finding is supported by reported iron deficiency 
$56 \mathrm{~d}$ after surgery in an adult patient (20). Early iron deficiency is a major concern because of known deleterious effects on brain development, including deficits in reading, math, spatial memory, and attention (21).

Hemopexin protein levels were also shown to be decreased by $50-60 \%$ during CPB in these patients. Hemopexin is an acute phase protein produced by the liver that is the major heme-binding protein in the blood. Free heme (containing iron) binds to hemopexin and is then taken up via endocytosis into liver cells or macrophages. It is this endocytosis that protects from the oxidative damage that can be induced by free heme when present in the blood. Hemopexin levels have been previously documented to change with hemolysis, however, these changes have been reported as both increases (22) and decreases (23).

The effect of hemolysis could be directly related to increased oxidative stress-related damage during and immediately after surgery. Although this response may be a result of inflammatory responses or ischemia-related damage, it seems to occur mainly as the result of hemolysis and the resulting release of redox-active iron from erythrocytes (24). This is validated in the present study and extended through our observations of the $\mathrm{Hb}$ and hemopexin relationships. Data presented in Figure 2 suggest that hemolysis results in a release of free $\mathrm{Hb}$ that initially may be moderated by the heme-scavenging protein hemopexin. However, significantly high levels of hemolysis persist even with the decrease in hemopexin, indicating that the heme-scavenging capacity of the blood may be compromised during surgery, which could lead to severe oxidative damage.

Other proteins observed in the study also play important roles in other potentially pathologic states. ITI-H4 is a member of a family of inter- $\alpha$-inhibitors that are produced in the liver and function as serine protease inhibitors in the blood. Many groups have reported a decrease in inter- $\alpha$-inhibitor proteins in patients with sepsis, and administration of interalpha inhibitor proteins has been shown to improve survival of patients with sepsis (25). Conversely, increases in levels of inter- $\alpha$-inhibitors, specifically ITI-H4, were observed with inflammation and acute phase reactions (26). Western blots identified a $60 \%$ decrease in ITI-H4 levels at time points 2 and 3 during CPB. It may be useful to monitor ITI-H4 protein levels during and after surgery to observe control over inflammatory processes during CPB. Inflammation is of particular concern as patients are currently treated with an antiinflammatory medication (methylprednisolone) during surgery.

Alpha-2-macroglobulin is an abundant plasma protein produced by the liver. Macroglobulins are involved in controlling inflammatory responses, especially when presented with pathogens. Two groups have reported significant decreases in levels of alpha-2-macroglobulin following CPB in adults (27). Initial 2-DIGE analysis revealed decreased levels of alpha-2macroglobulin following pediatric CPB. Analysis at all time points in 10 patients has revealed a $40-50 \%$ reduction in alpha-2-macroglobulin levels during CPB that persists even after $24 \mathrm{~h}$. Although low levels of ITI-H4 may indicate control over inflammation during surgery, levels of alpha-2- macroglobulin could serve as biomarkers of other inflammatory processes occurring during, and following, CPB in pediatric patients.

Catecholamines are naturally occurring compounds that stimulate the sympathetic nervous system. Serotonin directly affects contraction of smooth muscle venules, as well as the amplification of the effect of other endogenous vasoconstrictors and the release of norepinephrine. Both copper and iron have been demonstrated to be required for synthesis of biogenic amines, leading to their examination in pediatric cardiac patients following the observation of altered copper and iron levels.

The changes in circulating biogenic amines are noteworthy in that they display fundamentally different profiles. The observed epinephrine increases during surgery and the postsurgery norepinephrine increase, reflect increased sympathetic tone that is engaged to maintain peripheral resistance and is in agreement with previous findings from other studies (28). Circulating serotonin level changes are concerning for a number of reasons. First, the abrupt decline between time points 1 and 2 reflects a hemodilution following addition of adult donor blood. In general, infants display higher level of circulating serotonin. However, the persistent decrease maintained $24 \mathrm{~h}$ following CPB indicate that patients are not able to readily recover from the surgery-induced change. Plasma serotonin, both during and after open-heart surgery, was found to be significantly decreased during both extracorporeal circulation and hypothermia (29). Significant reductions in total serotonin concentrations (by approximately $65 \%$ ) have also been reported after adult cardiac surgery (30).

Another important observation from these studies is the consistent decreases in proteins that are produced by the liver (ITI-H4, alpha-2-macroglobulin, hemopexin, ceruloplasmin, apolipoproteins, and complement C3) (Figs. 1, 2, and Table 3 ). It is possible that this is an indicator of liver function and/or level of tissue perfusion during surgery. The slight decrease in hematocrit levels during CPB reveals a possible contribution of hemodilution to protein levels. Although it may play a role, it is unlikely that protein changes can be completely attributable to hemodilution. Nonetheless, observed changes are still important because of their roles in pathologic processes and normal homeostasis during $\mathrm{CPB}$, when their levels are low.

The results of this pilot study are promising, and illustrate the potential in identifying biomarkers of subtle biologic processes that are occurring during CPB procedures. Although this study is limited in sample size, and includes a diverse patient population, the ability to detect such robust and statistically significant changes in protein levels attributes to the fundamental nature of these changes. These changes seem to be independent of exogenous variables complicating the sample populations. It is also of note that a number of the changes observed have been documented in with similar procedures.

Further investigations of these biomarkers may lead to the improvement in the clinical outcomes in pediatric cardiac patients after CPB procedures. It will be important in future studies to identify any correlations between these biomarkers and patient clinical outcomes from days to years after surgery. 
Indeed, a larger study involving 50 pediatric patients is currently being collected to obtain the statistical power needed to make such correlations, and to identify more proteins involved in pathologic processes. The eventual goal of this research focuses on personalized surgical or therapeutic interventions that lower postoperative complication rates. It is also important to continue the use of discovery proteomics to uncover additional proteins that may serve as biomarkers of not only pathologic processes, but also of tissue damage and disease.

Acknowledgment. We thank Dr. Chuancai Wang for assistance with statistical analysis.

\section{REFERENCES}

1. Allen SW, Gauvreau K, Bloom BT, Jenkins KJ 2003 Evidence-based referral results in significantly reduced mortality after congenital heart surgery. Pediatrics 112:24-28

2. Jenkins KJ 2004 Risk adjustment for congenital heart surgery: the RACHS-1 method. Semin Thorac Cardiovasc Surg Pediatr Card Surg Annu 7:180-184

3. Boldt J, Kumle B, Papsdorf M, Hempelmann G 1998 Are circulating adhesion molecules specifically changed in cardiac surgical patients? Ann Thorac Surg 65:608-614

4. Vallely MP, Bannon PG, Kritharides L 2001 The systemic inflammatory response syndrome and off-pump cardiac surgery. Heart Surg Forum 4:S7-S13

5. Gentles TL, Gauvreau K, Mayer JE Jr, Fishberger SB, Burnett J, Colan SD, Newburger JW, Wernovsky G 1997 Functional outcome after the Fontan operation: factors influencing late morbidity. J Thorac Cardiovasc Surg 114:392-403

6. Chang RK, Rodriguez S, Lee M, Klitzner TS 2006 Risk factors for deaths occurring within 30 days and 1 year after hospital discharge for cardiac surgery among pediatric patients. Am Heart J 152:386-393

7. Miatton M, De WD, Francois K, Thiery E, Vingerhoets G 2007 Intellectual, neuropsychological, and behavioral functioning in children with tetralogy of Fallot. J Thorac Cardiovasc Surg 133:449-455

8. Oates RK, Turnbull JA, Simpson JM, Cartmill TB 1994 Parent and teacher perceptions of child behaviour following cardiac surgery. Acta Paediatr 83:1303-1307

9. O’Dougherty M, Berntson GG, Boysen ST, Wright FS, Teske D 1988 Psychophysiological predictors of attentional dysfunction in children with congenital heart defects. Psychophysiology 25:305-315

10. Freeman WM, Brebner K, Amara SG, Reed MS, Pohl J, Phillips AG 2005 Distinct proteomic profiles of amphetamine self-administration transitional states. Pharmacogenomics J 5:203-214

11. Lull ME, Freeman WM, Myers JL, Midgley F, Kimatian SJ, Ündar A, Vrana KE 2006 Plasma proteomics: a noninvasive window on pathology and pediatric cardiac surgery. ASAIO J 52:562-566

12. Freeman WM, Lull ME, Guilford MT, Vrana KE 2006 Depletion of abundant proteins from non-human primate serum for biomarker studies. Proteomics 6:31093113
13. Anderson NL, Anderson NG 2002 The human plasma proteome: history, character, and diagnostic prospects. Mol Cell Proteomics 1:845-867

14. Hye A, Lynham S, Thambisetty M, Causevic M, Campbell J, Byers HL, Hooper C, Rijsdijk F, Tabrizi SJ, Banner S, Shaw CE, Foy C, Poppe M, Archer N, Hamilton G, Powell J, Brown RG, Sham P, Ward M, Lovestone S 2006 Proteome-based plasma biomarkers for Alzheimer's disease. Brain 129:3042-3050

15. Fu Q, Van Eyk JE 2006 Proteomics and heart disease: identifying biomarkers of clinical utility. Expert Rev Proteomics 3:237-249

16. Matt P, Carrel T, White M, Lefkovits I, Van Eyk J 2007 Proteomics in cardiovascular surgery. J Thorac Cardiovasc Surg 133:210-215

17. Sheikh AM, Barrett C, Villamizar N, Alzate O, Miller S, Shelburn J, Lodge A, Lawson J, Jaggers J 2006 Proteomics of cerebral injury in a neonatal model of cardiopulmonary bypass with deep hypothermic circulatory arrest. J Thorac Cardiovasc Surg 132:820-828

18. Kono S, Suzuki H, Takahashi K, Takahashi Y, Shirakawa K, Murakawa Y, Yamaguchi S, Miyajima H 2006 Hepatic iron overload associated with a decreased serum ceruloplasmin level in a novel clinical type of aceruloplasminemia. Gastroenterology 131:240-245

19. Klomp LW, Gitlin JD 1996 Expression of the ceruloplasmin gene in the human retina and brain: implications for a pathogenic model in aceruloplasminemia. Hum Mol Genet 5:1989-1996

20. Aufricht C, Ties M, Salzer-Muhar U, Wimmer M, Herkner K, Haschke F 1995 Erythropoietin, erythropoesis and iron status in children after major surgical stress. Eur J Pediatr 154:458-461

21. Lozoff B 2000 Perinatal iron deficiency and the developing brain. Pediatr Res 48:137-139

22. Ascenzi P, Bocedi A, Visca P, Altruda F, Tolosano E, Beringhelli T, Fasano M 2005 Hemoglobin and heme scavenging. IUBMB life 57:749-759

23. Delanghe JR, Langlois MR 2001 Hemopexin: a review of biological aspects and the role in laboratory medicine. Clin Chim Acta 312:13-23

24. Christen S, Finckh B, Lykkesfeldt J, Gessler P, Frese-Schaper M, Nielsen P, Shmid ER, Schmitt B 2005 Oxidative stress precedes peak systemic inflammatory response in pediatric patients undergoing cardiopulmonary bypass operation. Free Radic Biol Med 38:1323-1332

25. Yang S, Lim Y-P, Zhou M, Salvemini P, Schwinn H, Josic D, Koo DJ, Chaudry IH, Wang P 2002 Administration of human inter- $\alpha$-inhibitors maintains hemodynamic stability and improved survival during sepsis. Crit Care Med 30:617-622

26. Daveau M, Jean L, Soury E, Olivier E, Masson S, Lyoumi S, Chan P, Hiron M, Libreton J-P, Husson A, Jegou S, Vaudry H, Salier J-P 1998 Hepatic and extrahepatic transcription of inter- $\alpha$-inhibitor family genes under normal or acute inflammatory conditions in rat. Arch Biochem Biophys 350:315-323

27. Cavaliere F, Crea MA, Martinelli L, Schiavello R 1991 [Loss of plasma protein in open-heart surgery]. Minerva Anestesiol 57:63-66

28. Gruber EM, Laussen PC, Casta A, Zimmerman AA, Zurakowski D, Reid R, Odegard KC, Chakravorti S, Davis PJ, McGowan FX Jr, Hickey PR, Hansen DD 2001 Stress response in infants undergoing cardiac surgery: a randomized study of fentanyl bolus, fentanyl infusion, and fentanyl-midazolam infusion. Anesth Analg 92:882890

29. Shida H, Morimoto M, Inokawa K, Kuroda T 1981 Changes of kallikrein and serotonin in plasma during and after open-heart surgery. Jpn Circ J 45:48-54

30. Breuer J, Georgaraki A, Sieverding L, Baden W, Apitz J 1996 Increased turnover of serotonin in children with pulmonary hypertension secondary to congenital heart disease. Pediatr Cardiol 17:214-219 